\title{
Mesaortitis luetic
}

\author{
Sophie Leiner, ${ }^{1}$ Sandra Folkmann, ${ }^{2}$ Marie-Theres Kasimir, ${ }^{1}$ Andreas Steiner ${ }^{1}$
}

${ }^{1}$ Department of Dermatology, Hietzing Hospital, Vienna, Austria

${ }^{2}$ Department of Cardiothoracic and Vascular Surgery, Hietzing Hospital, Vienna, Austria

\section{Correspondence to}

Dr Sophie Leiner,

sophie.leiner@wienkav.at

Accepted 29 August 2016
CrossMark

\section{To cite: Leiner $S$,} Folkmann S, Kasimir M-T, et al. BMJ Case Rep Published online: [please include Day Month Year] doi:10.1136/bcr-2016216479

\section{DESCRIPTION}

A middle-aged patient was admitted to the hospital for surgical repair of an aortic aneurysm (figure 1A). As part of routine preoperative testing, performed especially in patients with aortic aneurysms, the patient tested positive for late syphilis. The patient denied having had any previous therapy for syphilis. The patient was therefore suspected of suffering from cardiovascular syphilis presenting clinically with an aortic aneurysm. Neurosyphilis was excluded.

The patient then underwent surgery (figure 1B) and was treated with doxycycline $100 \mathrm{mg}$ per orally two times a day for 30 days because of a known penicillin allergy.

The histopathological examinations of the aortic aneurysm showed a degeneration of the elastic fibres as well as mucoid degenerations (figure 2). The vasa vasorum were surrounded by dense lymphoplasmocellular infiltrates (figure 3). These results were consistent with mesaortitis luetic. The treponema immunostain did not detect any spirochaetes; however, this is not unusual in cardiovascular syphilis as it is a pathogen-poor stage of syphilis. ${ }^{12}$ The patient was finally released in good condition from the hospital.

Mesaortitis luica is a form of cardiovascular syphilis that can present within the context of tertiary stage syphilis. ${ }^{12}$ Since the antibiotic therapy was introduced the incidence of cardiovascular

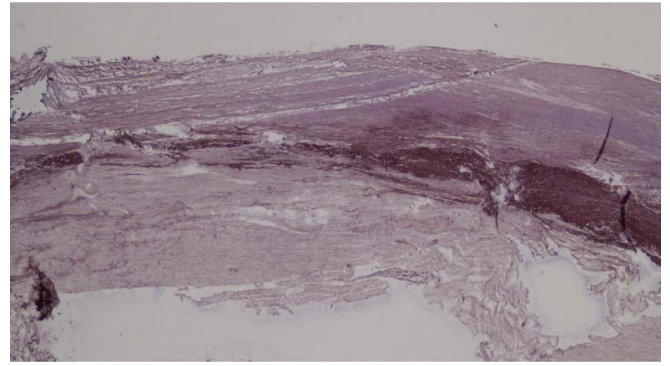

Figure 2 Histopathology slide of the aortic aneurysm: in the left part of the picture a clear reduction of the elastic fibres in the medial layer can be seen.

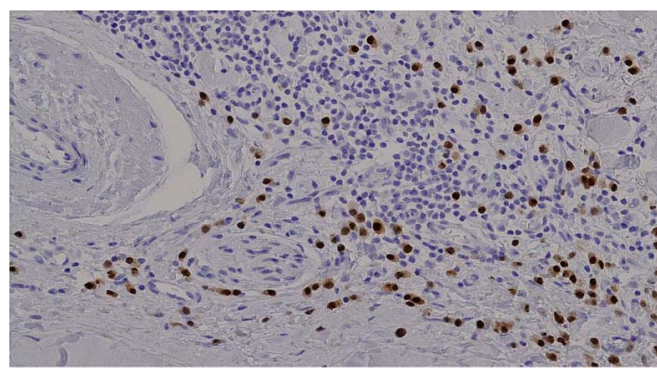

Figure 3 Histopathology slide of the aortic aneurysm: around the vasa vasorum dense lymphoplasmacellular infiltrates can be seen. The plasma cells are recognisable by the marker multiple myeloma oncogene 1 .
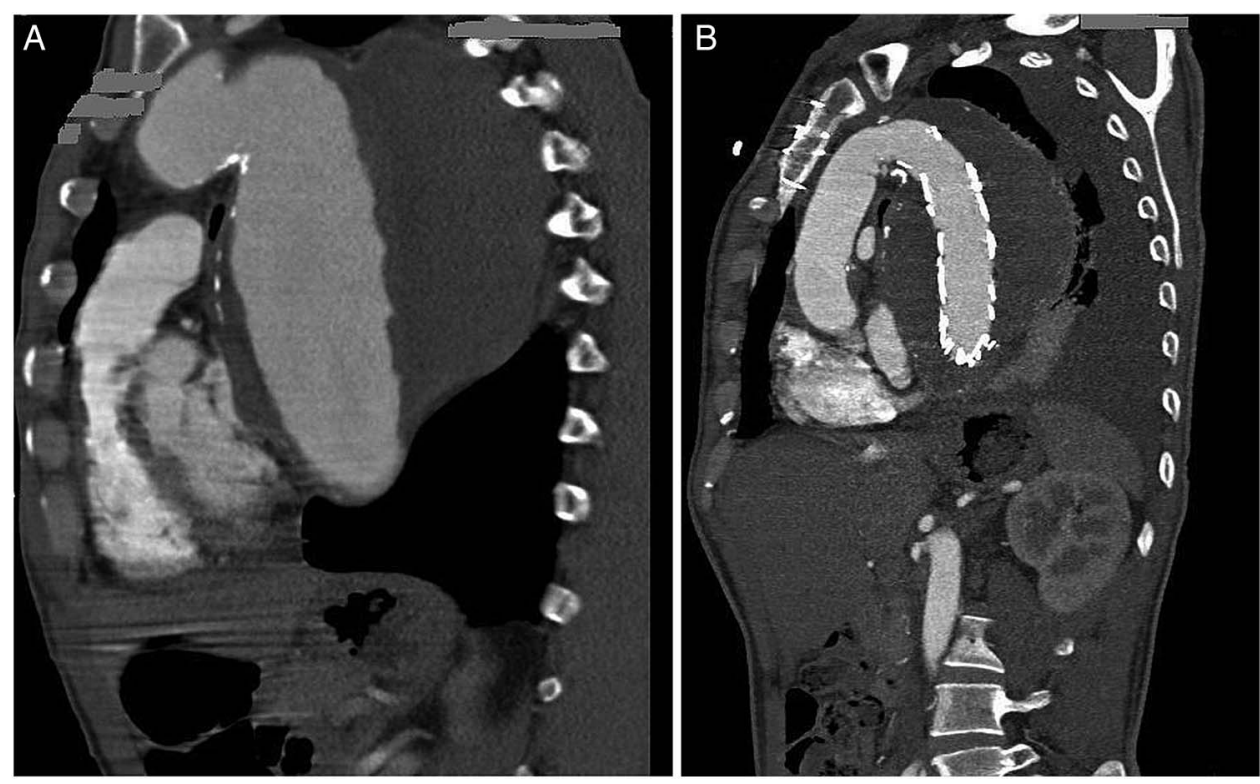

Figure 1 (A) Preoperative CT scan: aortic aneurysm of the aortic arch and the ascending aorta (maximum diameter $12 \mathrm{~cm}$ ). Courtesy of professor Rand, Department of Radiology, Hietzing hospital. (B) Postoperative CT scan: vascular prosthesis and stent in situ. The operation consisted of a vascular prosthesis of both the ascending aorta and the aortic arch. Furthermore the patient received a stent of the proximal descending aorta which was then extended into the thorax. Courtesy of professor Rand, Department of Radiology, Hietzing hospital. 
syphilis dropped to $<0.1 \%$. $^{3}$ The pathogenesis of cardiovascular syphilis is an obliterating endarteritis of the vasa vasorum. ${ }^{2}$ The aortic media becomes ischaemic and smooth muscle cells as well as elastic features can get lost. ${ }^{2}$ This process results in dilation of the aorta, aneurysm and insufficiency of the aortic valves. ${ }^{12}$

\section{Learning points}

- If you see patients with late syphilis you should exclude tertiary stage syphilis. A chest X-ray is a good screening method for detecting an aortic aneurysm.

- Although a rare disease cardiovascular syphilis should be considered as a differential diagnosis in aortic aneurysm.

Acknowledgements Dr Breier served as scientific advisor. Dr Mertikian: provided preoperative and postoperative CT scans. Professor Rand provided preoperative and postoperative CT scans. Dr Stella critically reviewed the study proposal and served as scientific advisor.

Contributors All authors included fulfilled the criteria of authorship. All authors have substantially contributed to the conception of the work and revised it critically for important intellectual content. SL substantially contributed to the design of the work, the acquisition and interpretation of data and drafting of the content. SF and $\mathrm{M}$-TK revised the content. AS contributed to the interpretation of data.

Competing interests None declared.

Patient consent Not obtained.

Provenance and peer review Not commissioned; externally peer reviewed.

\section{REFERENCES}

1 Horváth A. Chapter 11 biology and natural history of syphilis. In: Gross G, Tyring SK, eds. Sexually transmitted infections and sexually transmitted diseases. Berlin, Heidelberg: Springer-Verlag, 2011:129-41.

2 Stone JR, Bruneval P, Angelini A, et al. Consensus statement on surgical pathology of the aorta from the Society for Cardiovascular Pathology and the Association for European Cardiovascular Pathology: I. Inflammatory diseases. Cardiovasc Pathol 2015;24:267-78.

3 Heggtveit HA. Syphilitic aortitis. A Clinicopathologic Autopsy Study of 100 cases, 1950 to 1960 . Circulation 1964;29:346-55.

Copyright 2016 BMJ Publishing Group. All rights reserved. For permission to reuse any of this content visit

http://group.bmj.com/group/rights-licensing/permissions.

BMJ Case Report Fellows may re-use this article for personal use and teaching without any further permission.

Become a Fellow of BMJ Case Reports today and you can:

- Submit as many cases as you like

- Enjoy fast sympathetic peer review and rapid publication of accepted articles

- Access all the published articles

- Re-use any of the published material for personal use and teaching without further permission

For information on Institutional Fellowships contact consortiasales@bmjgroup.com

Visit casereports.bmj.com for more articles like this and to become a Fellow 